\title{
1. Business and public policy: introducing the field
}

\author{
Aynsley Kellow, Tony Porter and Karsten Ronit
}

What is the relationship between business and public policy? Daily news headlines about the corrupting influence of business on government, governmental success in collaborating with business to implement policies in new ways, or international trade and investment negotiations, are all reminders, along with countless others, that business and public policy are interwoven in a great variety of complex and often very high-stakes ways. This complex relationship between business and public policy is evolving through time, together with the accumulated understandings of this relationship generated by those who study it, adding further complexity. In this chapter we provide an overview of this evolution, highlighting key continuities and changes, pointing both to insights that have illuminated the relationship between business and public policy, and gaps in our knowledge that remain to be explored.

The chapter is organized into three sections. The first section of this chapter sets out key features of the practice and study of business and public policy that have remained continuously relevant throughout the decades since World War II. These key features include characteristics of and variations within the three main types of actors that are relevant to this field of practice and study - government, business and civil society. These key features also include characteristics of the interactions between these key actors.

The second section of this chapter focuses on three interrelated processes of change evident as the practice and study of business and public policy has evolved. The first process of change is a generalized shift from more formal hierarchical organization to more fluid networked organization, which has affected all three types of actors. The second process of change is a much more active and direct contesting of business authority by civil society in the making of public policy. The third process of change is globalization, which has shifted the focus of business and public policy away from a more exclusive focus on the nation-state to one that includes cross-border and global locations and issues.

The third and concluding section of this chapter highlights the relevance of insights from the field of business and public policy for some urgent and crucial contemporary public problems, pointing to some future research directions for the field.

Understanding this process of historical transformation is helpful not just in appreciating the legacy of the near past, but also in anticipating the future, and what questions need to be asked about it. These questions have an urgency that is amplified by the severity of current challenges that the relationship between business and public policy is implicated in and expectations about the activation or altering of this 
relationship that may be required if solutions are to be found. This includes problems such as climate change, financial crisis, pandemics, disruptive technologies, precarious employment, backlash against globalization or growing social inequality. While these go far beyond the scope of this chapter, the continuities and changes that we highlight in the evolving relationship between business and public policy point to the centrality of this relationship in both contributing to and addressing proliferating challenges of this type.

\section{MAPPING CONTINUITIES IN THE RELATIONSHIPS BETWEEN BUSINESS AND PUBLIC POLICY}

In this section, we discuss the key features of the interactions between business and public policy that have been apparent through their evolving histories. We may trace the study of business and public policy far back in history. For instance, the emergence of writing and numbers can be traced back to such innovations in ancient societies as the use of clay tablets for recording market transactions and the taxes that financed empires and the states associated with them. In medieval times, key organizations, such as guilds, emerged and became for centuries important for the regulation of markets.

However, for the purposes of this Handbook, we are interested in the more contemporary practices and study of the interactions of business and public policy. The end of World War II marked an important historical moment where the horizontally integrated cartel form of business organization that had been important globally in the period before and between the two world wars, was delegitimized by its importance for the defeated Axis powers, and was displaced by the large, vertically integrated but relatively independent multinational corporation that had become most prominent in the newly globally hegemonic United States (Porter, 1999). In this section we map out the key properties of the global field of interactions between business and public policy that are especially apparent in this post-World War II period. In the section that follows this one, we then discuss the changes that have occurred over the more than seven decades since the end of World War II.

Throughout the period since World War II we can identify three types of actors as especially relevant to business and public policy: government, business and civil society. Public institutions can be understood in many ways as governments, parliaments, political parties, regulatory agencies, and many more, whose actions are sometimes very general in the form of overall intentions and ideologies and at other times highly specific in terms of targeted legislation (Hollingsworth et al., 1997b). Business actors can also be conceived in different ways, from the manifest role of corporations, networks and associations (Lehmbruch, 1984) to the not less important role of strong but elusive market forces shaping political thinking and setting boundaries for interventions. We may think of civil society as both a vaguely defined general public, or citizenry, which also constitutes a market of customers to business. We may also think of civil society as specific non-governmental organizations, social 
movements, citizens and consumer groups, that can be similar to business in the size of their revenues and organizational forms.

We may ask about the directions of policy-relevant power and influence among these three types of actors. For instance, governments may shape business, or the reverse, just as business might shape citizens in ways relevant to public policy, or the reverse, or business may shape its own interactions. In this section, we focus especially on the more basic interactions associated with business and public policy before we turn to the growing complexity in the next section, where stronger emphasis is also put on the role of civil society in challenging business. In the remainder of this section, we start by examining the significance of variations in the organization of government, before turning to the significance in variations in the organization of business, including how it exercises power, before finally turning to the role of civil society. The most important current roles of civil society have emerged in recent decades, and these are addressed more fully in the subsequent section on change over time.

\section{Variations in the Role of Governments and Polities}

The interactions between business and public policy are shaped by government, broadly defined to include all public institutions and the polities associated with them. Many analyses of the relationship between business and public policy place particular emphasis on conceptualizing the character of governments and polities and the place of business interests in them. At any particular moment, polities will have inherited distinctive configurations of business and government from the past, showing interesting continuities.

Following World War II, polities in which business was permitted to play an independent role displayed important differences in the character of the interactions between government and business. A key way of analysing this has been through research on varieties of capitalism inspired especially by Hall and Soskice's (2001) distinction between liberal market economies, exemplified by the US and the UK, and coordinated market economies, exemplified by Germany. Each of these display institutional complementarities between legal systems, labour markets, training systems, financial systems, and the relationship between business and public policy.

These types of cross-national distinctions have also been differentiated, for instance in the work of Whitley (2007), who identified varieties of national business systems, or Hollingsworth and Boyer (1997a), who identified variations in social systems of production. This body of research overlaps with studies of variation across forms of corporatism and policy networks. For instance, Streeck and Schmitter (1985) differentiated between four guiding principles of social orders that appear in different mixes: community, market, state and associations and put emphasis on the role played by organized business interests in society. As discussed further below, there are divergent views on whether these distinctions are being erased over time by globalization and neoliberalism (Soederberg et al., 2005) or are likely to persist 
(Whitley, 2007) but they are sufficiently long-lasting to be considered enduring continuities in the relationship between business and public policy.

Overall, this literature is more concerned with sources of economic growth and innovation and how governments might amplify these than with the regulation of business, but this literature also provides valuable insights into the legacy of historical path dependencies in the constitution of the field within which interactions between business and public policy take place. In societies such as Germany or Japan there is a long tradition of close collaboration among businesses and between business and government, while in societies such as the US and the UK there is a long tradition of more autonomously organized markets, with more adversarial, opportunist, or ad hoc interactions between the two types of actors. These historical path dependencies also shape variations in the forms of business organization.

There is a long and productive history of analysing the relationship of the state to business as an expression of the dominance of capital as a social class, often drawing on ideas originally inspired by Karl Marx. There has been a vigorous debate within the Marxist tradition on the relationship between the state and capital, for instance between those such as Ralph Miliband who saw the state primarily as an instrument of capital, and those such as Nicos Poulantzas, who saw the state as a more structural location within which capital and other classes contended for power, even if those structural properties tended to continually reproduce capitalism (on this debate see Barrow, 2002). The macro-structural character of this type of analysis and its starting assumption that capitalism continually reproduces the dominance of capital, has tended to direct its attention away from the more nuanced and detailed analysis of particular public policies that has been more central to the field of business and public policy. Therefore, many of these otherwise interesting debates have not been taken up in other kinds of scholarship on business and public policy. Nevertheless, its more holistic emphasis on the more ubiquitous and structural features of business can be valuable in explaining the persistence of outcomes that may favour the largest and most powerful business interests and how these change over time.

Other approaches also examine the way that the state may shape the power of business. The demand for business political action can be reduced in cases where governments and other public institutions play a proactive role in the promotion of business interests and adopt regulation to meet either the general interest of business or the interests of specific industries or corporations. In a number of cases, legislators do not need to interact with business as they already have a profound understanding of the concerns of business and what kind of public policy is needed. Indeed, business-friendly political parties and governments see it as one of their primary obligations to provide optimal conditions for business (Fuchs, 2005, 2007). Less directly, public policy and regulation may inspire the mobilization of business influence (Pierson, 1993), a common feature in countries where there is much regulation of business, such as in continental Europe, but also in the US where regulatory policy in the late 1960s and early 1970s encouraged the coordination of business, for instance manifested by the Business Roundtable, the United States Chamber of Commerce, and the National Federation of Independent Business (Vogel, 1989: 13-14). Indeed, 
it has been an important element in neo-corporatist research that states play an active role in the shaping of business collective action, a point we shall return to below.

In conceptualizing polities, some theorists have imagined business to be simply one among myriad interest groups that participate in the process by which policy is made. David Truman described this in his classic work The Governmental Process (1971), and Robert Dahl found in the fragmentation of power among many groups a reassuring kind of "Madisonian" democracy (Dahl, 1973). But before the ink was dry on these writings, critics began to question whether business was not represented by groups that enjoyed more influence than others - that business was not at least primus inter pares. E. E. Schattschneider (a contemporary of Truman's) pointed to the relative difficulty of different interests in organizing into groups, suggesting that organization was the "mobilisation of bias", with the result that (in his classic phrase) "the choir in the pluralist heaven sings with a decidedly upper middle class accent" (Schattschneider, 1975). C. Wright Mills identified a "power-elite" that brought together business, political and military elites, a step closer to the view of business interests as consolidated and dominant that characterizes the Marxist tradition.

\section{Variations in the Organizational Form of Business}

The literatures on business and public policy have also focused on the organization of business. This includes identification of different types of business actors, as well as variations in how business exercises power and is involved in formulation and implementation of public policy.

There is a substantial literature that highlights the role of individual corporations, albeit with a strong bias, no doubt reflecting reality, towards large corporations, including multinational corporations (MNCs) active in both domestic and international contexts (Muzaka, 2009; Nölke and May, 2018; Ruggie, 2018). At this juncture, we move into other areas of research not always strongly associated with the study of public policy per se, where specialists on corporate affairs are less inclined to address public policy, and where public policy scholars are inattentive to the specific role of business. Corporations occupy a central role in, for instance, management studies, and in some parts of this research it is recognized that corporations are not just active in the contexts of markets, but also have a political role to play. This role may involve influencing governmental processes or it may be more reliant on the public policy effects that can be directly created by a corporate structure, as with the vast and lively area of corporate social responsibility (CSR) or the role of environmental, social and governance factors in investing and corporate governance. MNCs are also recognized as political actors in the area of international political economy, a point we shall return to later in this chapter, and in many cases they have a potential to influence public policy. At domestic and international levels, these corporations have overwhelming resources to invest in public affairs and significant opportunities to influence public policy, while small and medium-sized enterprises (SMEs) are generally inferior in many political respects and seemingly less inclined to leverage public authorities, and they have not attracted the same scholarly interest 
in studies on business and public policy. A stronger effort is therefore needed to approach business as a differentiated category and to recognize the huge variation in the capabilities of business in policy-making.

The literature that has most productively explored finer variations in how business interacts with public policy focuses on the associational activities of business. In the aftermath of World War II, these most often involved industry associations organized nationally. The complicity of industry cartels in German and Japanese militarism and World War II helped fuel a global strengthening of anti-trust and competition policies that prohibited collusion in setting prices or the dividing up of markets, but business associations carved out an important role in representing business interests to government and in solving industry collective action problems in many domestic and international contexts (Ronit, 2018; Schmitter and Streeck, 1999). Many interest groups face challenges of collective action and there is a risk that individual capacitated actors in business, such as large corporations, will free-ride and escape cooperation. Compared to other groups in society, however, business is generally characterized by consisting of a relatively small number of firms likely to benefit from the general advantages of small-size group in developing collective action (Olson, 1965). As such, business tends to be privileged in society and is better suited for collective action than, for instance, workers or consumers that form very large and heterogeneous groups, although many aspects of domestic and international associability remain to be studied (Kellow, 2002).

In a way, this is a strange irony because firms with similar profiles in such comparatively small groups also tend to be active in the same market, and are thus competitors, a factor that on the other hand should complicate cooperation. Thus, a thin line must be walked in business associations when defining political action. These two opposing trends emphasizing the advantages and barriers in the formulation of policy are, however, both understudied and undertheorized. Business associations not only deliver input into the policy process but they also have the capacity to share responsibility for the formulation of policy and in some cases take part in the implementation of public policy, and, therefore, their role is not reducible to "pressure groups" as it is often anticipated.

The key here is the concept of "associability": how do firms that are competitors find a basis for association into interest groups? Lowi (1964) suggested that the answer lay in the nature of what was at stake with the policy under consideration. Individual firms would become politically active to secure benefits that accrued only to them (distributive policies). Interest groups would form and contest policies that regulated them (regulatory policies). Policies that involved choices between something approaching classes would serve as the basis for peak associations (redistributive policies). Pierson (1993) later added a temporal dimension, noting that feedback from policy affected subsequent associations that formed on the template of policies. Traxler and Schmitter (1995) also emphasized the importance of political institutions for associability, with different impacts by subnational, national and supranational institutions (what Lowi, 2001 called micro, meso and macro). These points are not 
necessarily distinct, as Pierson (2006) also suggested policies themselves could be seen as institutions.

The organizational forms of business can also be studied from different perspectives of power. Power is one of the most contested, ambiguous, and also important concepts in the social sciences, and this is the case for the study of business and public policy as well, as different kinds of influences can be envisaged. Summing up some existing approaches, Fuchs (2007) has provided a helpful three-fold typology for understanding the ways in which business can exercise power in public policy. Similar to the forms of business organization discussed above, we can study these as incompatible differences in perspective, or differences that can be present simultaneously in the exercise of power by business.

The first approach to business power can be characterized as instrumentalism. This involves the direct and deliberate exercise of power by one actor to change the conduct of a second actor, most often by the deployment of material resources possessed by the first actor. This is valuable, for instance, in analysing business corruption, or forms of regulatory capture where business manipulates regulators by offering lucrative employment after they leave a regulatory agency. However, it is a relatively narrow approach to power that misses other forms.

The second approach to business power can be termed structural. This approach traces the sources of business power to the structural features of capitalist societies. For instance, Charles E. Lindblom (1983) emphasized that business provided the means by which most voters derive their incomes, and from both governments derive their revenue. By promising to invest or disinvest in a particular jurisdiction, business can therefore exert greater leverage than other actors - and it can do so quietly, without having to engage in noisy protest action. Business also has a capacity to ensure that some issues never reach the political agenda and therefore are not addressed by public policy. As discussed in the classic work by Bachrach and Baratz in which the phrase "non-decision making" was coined (Bachrach and Baratz, 1963), business, as a powerful interest in society, may be successful in avoiding or sidelining certain unpleasant issues reaching the political agenda. Indeed, business has a key interest in not surrendering authority and in keeping certain prerogatives at the firm level (Offe and Wiesenthal, 1980), and firms are authority structures themselves which gives business certain advantages compared to labour which is compelled to organize in a collective framework. Indeed, if private enterprise is considered such an important factor that it cannot be challenged without eroding core values and institutions in society, business can have an enormous influence on public policy, and sometimes on the lack of policy.

The third approach relevant to study is the discursive dimension, which offers a number of opportunities to interpret and frame issues and situations. There are multiple ways in which discursive power can be exercised in relation to public policy. It can include public relations, when business seeks to influence the views of government and the public through media campaigns. It can include more pervasive and implicit ideologies, which render some policies as seemingly common sense, and others as simply unimaginable. A frequent cited example is the ideology of 
neoliberalism, or market fundamentalism, which assumes that society is made up of self-interested atomized individuals, and then continually calls for the application of market-like solutions to all public policy problems. It can also include the more "performative" power of language, which can create the very thing it purports to describe. An example is a piece of intellectual property, which could only be brought into existence with the legal language that constituted it as such. Many economic objects that are important to business and public policy similarly would not have been brought into existence without the creative effects of language or the discursive uses of numbers, as with financial derivatives, or the data trends that can move financial markets (De Goede, 2001; MacKenzie, 2008), and business interests often fund or otherwise enable such forms of discursive power. Put simply, law can only govern what it can describe, and those who make the description are influential.

\section{Variations in the Role of Civil Society}

Actors other than government and business often are significant for business and public policy. Of course, various civil society groups have played a strong role, and business needs to relate to these groups in as well as beyond markets, when, for instance, it can be crucial for the economic well-being of business and improve the reputation of business in society. At the same time, government regulations have traditionally taken into account the implications of business activity for wider groups in society, not least because there can be a strong demand for regulation that provides such groups with a number of rights and because such groups have concrete interests.

Such relations between business and civil society have often been conflictual. There have also been attempts to characterize relations as potentially more cooperative. The above forms of business power can be enhanced when business interests create tacit or explicit alliances with other actors to influence policy. Bruce Yandle suggested a "Bootleggers and Baptist" theory (really a model) of regulation based on his observation of the prohibition on the sale of alcohol on a Sunday, growing up in the US state of Georgia (Yandle, 1983; see also Yandle and Buck, 2002). This suggests that regulatory policies are often supported by those who believe an activity is morally wrong and should be prohibited (the Baptists) and those who can only make money if they can provide an illegal service free from the competition legal sellers would provide (the Bootleggers). Not only does the moral argument strengthen the push for policy action, but it provides a cloak to mask what would otherwise be clear as patent support for self-interest. Such coalitions are not necessarily formalized. Braithwaite and Drahos (2000) have similarly pointed to the ways that divisions within business can be exploited by civil society organizations, for instance through the strategic use of competition policy or the promotion of a particular set of best practices.

A particularly important type of civil society organization that can work together with business is labour unions. Because relations between employers and workers have been a crucial element and in many cases have provided societies with a certain 
stability, the integration of civil society in public policy has also been an element of continuity.

In countries with a high degree of unionization and institutionalization of labour markets, such as in Western Europe, many problems are resolved through negotiations between organized employers and workers, with or without the involvement of public authority. They span a variety of social and economic issues, such as wages, working hours, holidays, work environment, education and training, insurance, pension schemes, etc. When representative employer organizations and unions stand behind them, policies can be relevant and solid alternatives to traditional public policy and in many cases perhaps function even better. Hence, a conflict line in public policy is whether to manage issues by organized interests or government. There is a highly established tradition in research for examining these aspects of industrial relations and the different kinds of public policy they embrace in welfare societies (Manow and Ebbinghaus, 2006). In this field, however, research is rarely formulated explicitly and entirely in terms of public policy, or vice versa, and there is therefore a need to bridge different research traditions.

In the next section we shall see that civil society has become much more engaged with business and public policy, in more varied and integrated ways, than was typically the case in the decades immediately following World War II.

\section{THE CHANGING RELATIONSHIPS BETWEEN BUSINESS AND PUBLIC POLICY}

In the decades since the end of World War II there have been profound changes in the relationships between business and public policy as part of the broader restructuring of our societies, even if the continuities that were highlighted in the previous sections remain visible. Some of these changes are also specific to the organization of business, of the state, of civil society or of the interactions between these.

Three interrelated changes have been especially significant, and this section will examine them in turn. The first is the increasing multiplicity, fluidity and hybridity of the actors and relationships associated with business and public policy. The second is the growing role of civil society organizations in the interactions between business and public policy. The third is stronger globalization, which has been closely associated with business and public policy. These changes are manifested in different ways: public policies come in various hybrids bringing different policies together; policies involve a diversity of public and private actors that bring different assets into policy-making; and public policy is increasingly internationalized and globalized.

\section{Increasing Multiplicity, Fluidity and Hybridity}

A broad historical change that is evident across a great many dimensions of contemporary life is the increasing institutional fluidity and hybridity in contemporary societies. Often this is interpreted as a shift from clearly bounded hierarchical forms 
of organization to network forms at both domestic and international levels (Castells, 2000; Ferguson, 2018; Slaughter, 2017). It may alternatively be interpreted as an expression of social acceleration (Rosa, 2015), where technological, economic and cultural factors are contributing to a speeding up of human experience, destabilizing formal institutions. It can be interpreted as part of the evolution of societies, when incessant critical inquiry starts to undermine traditional and foundational beliefs, replacing for instance government regulation with a stronger emphasis on markets, as expressed in supply side economics and New Public Management ideas, or with the proliferation of "best practices" in business and experimentalism in public policy (De Búrca et al., 2014; Overdevest and Zeitlin, 2018; Zeitlin, 2015).

These changes are evident in the restructuring of business that has occurred over the decades since World War II. Although the 1950s marked the ascendancy of globally active US-based multinational corporations, in the initial decades after World War II business was primarily organized on national lines, with the global operations of MNCs such as in the auto industry often involving a series of replicas of the home operations designed to sell to the national host market. In the industrial economies of the Global North, this period, often labelled Fordism (Watson, 2019), included mass production, national bargaining between employers and labour, and the expansion of the social welfare state. Firms were organized hierarchically, funding their expansion through retained profits (Fligstein, 2013). Business-governmental relations were often organized in predictable centralized ways, as with European "concertation" between peak industry associations, big labour unions, and government, a period recognized by a theorizing about corporatism (Grote and Schmitter, 1999; Grote et al., 2008; Schmitter, 1974).

Beginning in the 1960s, also reflected in new approaches in business schools, this model began shifting towards more networked forms, as hierarchies were flattened, internal functions were outsourced to suppliers, and financial markets contributed towards challenging the stability of business, for instance with a wave of restructuring by corporate raiders drawing on junk bond markets. New innovations challenged traditional industry boundaries, as with the introduction of electronics technologies into automobiles, or biotechnological innovations at the intersection of agriculture and chemistry. Growing social fluidity undermined the effectiveness of mass production, while robotics and other new production technologies enabled more flexibility in seeking out higher return niche markets (Piore and Sabel, 2000). As part of this development, relocations of firms and outsourcing of activities took place. Interestingly, a range of new industries emerged, a process that also demanded new skills and educations in the labour force, all issues giving rise to the development of new policy fields.

Simultaneously, similar changes were evident in the restructuring of states. This period saw a worldwide growth in the delegation of governance by states to relatively independent regulatory agencies, and then to private forms of regulation and self-regulation. The wave of market-oriented public policy reforms that began in the 1980s, associated with labels such as the New Public Management or neoliberalism, began to introduce such market practices as competition and benchmarking into 
government, along with waves of privatization of state enterprises and other governmental responsibilities. Regulators and officials in specialized government ministries began to interact directly with their counterparts in other countries with increasing intensity. The formulation of public policy increasingly migrated from formal legislative processes to policy networks bringing governmental and business actors together in often quite autonomous networked settings cutting across more traditional boundaries of the bureaucratic state (Atkinson and Coleman, 1992; Tsingou, 2014).

Research has taken an interest in examining a wider variety of actors, networks and alliances that occupy a place in the formation of public policy (Salisbury, 1984). In this perspective, it also becomes difficult to categorize actors in public policy as simply made up of regulators and regulatees, an otherwise common and useful distinction in regulation theory (Baldwin et al., 2012). Today, there are, for instance, many actors that monitor and evaluate developments in public policy, and act as third parties (Gunningham et al., 1999). They also disseminate information to particular interested parties or to the society in general, and, thus, they contribute to a better understanding of the effectiveness of policy. Despite this growing complexity and diversity, particular government agencies representing public authority and actors that can speak authoritatively for relevant business interests usually are central (Baker, 1999). It is important to stress this pattern and not see public policy in areas with strong impact on business as moulded by a confusing array of actors.

\section{Growing Role of Civil Society Organizations}

Civil society is a somewhat amorphous category, containing activists as well as formal organizations, and, hence, a plethora of concepts also exists to embrace civil society actors. For our purpose, it is useful to distinguish between those parts of civil society that are organized to engage directly with business, and those parts that do not necessarily address business as such but have wider purposes in society (Ronit, 2007a, 2007b). As to the former category, we may include both consumers and workers who enter into contractual relations with corporations in the market and therefore have specific opportunities to influence business as countervailing powers (Galbraith, 1952), as the direct support or opposition from these groups is important. Also other groups, not involved in market exchanges per se, interact with business. These groups may all approach public policy but from different angles and with different consequences for business. Interestingly, the role of labour is rarely treated as a civil society group, and we find studies on unions in other areas of research, for instance in analyses on industrial relations. These distinctions are important when we refer to the growing role of civil society. In many contexts, it seems that the strength of unions has declined, while the role of many other forces in civil society has become stronger.

Civil society organizations can have a significant and direct impact on business, but various forms of activism are also targeted at governments when lack or lapses in business regulation are identified. This is seen in some policy fields more than in others. Classic areas relate to the labour market and consumer goods markets. In 
other areas, such as human rights policy, important organizations in civil society have increasingly come to play a key role and engage in critical monitoring of business in ways that question corporate practices with the effect that the reputation of firms is damaged if they fail to comply with specific norms and standards (Ruggie, 2014). In other words, civil society assumes roles that otherwise could be taken by governments or intergovernmental organizations.

While there is a long history of civil society organizations having impacts on the interactions between business and public policy, such as transnational anti-slavery and labour activism in the nineteenth century, and the interactions of business and labour in governing working conditions in the mid-twentieth century, we can see a growing influence and sophistication of civil society organizations through the decades following World War II. Over the last decades, we have witnessed an increasing portfolio of schemes on behalf of industries and corporations, promoted under the concept of corporate social responsibility (Carroll, 2008), but also found under many other names. Some of these business initiatives are hollow and of no value to public policy and the major motive behind them is simply to weaken protest and forestall regulation. From the perspective of governments, such private initiatives can be an excuse for not taking appropriate action. However, some initiatives in business may contribute to problem-solving in society. As such, they may serve functions usually performed by traditional public policy, although many private initiatives are taken by single firms or small groups of committed corporations, and it is one of the weak sides of these schemes that they are mainly adopted by large corporations.

As discussed, civil society has a potential to leverage and enter into formal relations with business and through contracts establish norms and rules to govern corporate behaviour, but in some cases, there are opportunities for civil society to take a step further and design schemes to regulate business in different stages of the production and value chain. In such cases, civil society has an authority to define public policy. Civil society has in many ways a moral authority, a key quality in influencing opinions on business in society, but civil society hosts additional capacities. First, civil society may adopt a more critical and radical view of various business practices and may have the courage to challenge existing business authority. Second, civil society may dispose of expert knowledge and be guided by alternative perspectives and use this position to establish norms and rules. For some sections of business, criticism is unwelcome but for other parts of the business community new and alternative norms and rules presented by civil society organizations are rather seen as an opportunity. These efforts of civil society have a potential to influence public policy.

Specific civil society organizations have engaged in rule-making activities alone, or in some cases together with interested corporations or groups in the business community in the form of multi-stakeholder arrangements (Havinga, 2015), and business is encouraged to join such schemes on a voluntary basis. A particularly rich activity has developed in relation to environment policy. Thus, civil society initiatives belong to a wider case of self-regulation, a strong historical tradition in business (Greif, 2005). When joining such private schemes, firms have to comply with rules set by actors outside business and the critical monitoring provided by the schemes and 
the organizations behind them have another character than when firms define their own codes of conduct. In some ways, these initiatives share features with traditional public regulation of business, where norms and rules in society are imposed on business. When firms comply, they are provided a "social licence" to operate that can be very valuable and give some advantages in relation to competitors in the market but also enhance their reputation in society more broadly. Although there can be serious problems associated with such arrangements (Vogel, 2007), this example shows that business and public policy can best be understood if we are sensitive to the role of business in a variety of institutional contexts.

Studies on civil society action and related business responses are mainly found in social movement research or in management studies, and they tend not to engage with the public policy literature although many issues are exciting in terms of public policy. At the same time, we can observe a lack of attention in public policy studies to processes that link business and civil society and unfold beyond public institutions. A better understanding of the potentials and pitfalls in alternative forms of public policy can therefore be achieved, if we bring the various traditions closer together.

\section{Stronger Globalization}

A major historical change since World War II is globalization. This change also involves the erosion of boundaries, and greater reliance on markets discussed above. On the business side, this has been accompanied by the growth of global supply chains, or value chains, connected with a great variety of organizational forms, ranging from arm's length markets through various contractual relationships to operations wholly owned by the dominant firm in the global value chain. It has been accompanied by growing capacities of businesses from the Global South, and by intense interest on the part of business in a growing number of global public policies, such as trade and investment liberalization, needed to facilitate these types of restructuring. These have contributed to a proliferation of international and global business associations and advocacy activities, often in ad hoc flexible arrangements tailored to particular fast-moving policy developments.

These changes have been analysed by a large and illuminating literature on global value chain governance (Gereffi, 2014; Ponte and Sturgeon, 2014) with two significant implications for business and public policy. First, these new forms of cross-border production have required new forms of governance that can cope with the distance, speed, and lack of global governmental capacity, and a proliferation of private forms of governance has resulted, both within supply chains, such as through contracts or logistical systems, and with third parties such as private standard setting bodies and certifiers. This literature has identified, for instance, differences between global value chains dominated by producers, as in the auto industry, and those dominated by retailers, as in the food industry. Second, there have been countless efforts by scholars, activists and governments to explore the way these forms of private governance can be enlisted in the pursuit of social or environmental policies that go beyond maximizing profits. This could be accomplished by leveraging the 
power of the state to regulate extraterritorially through the value chain (Crasnic et al., 2017), or to demand certain private standards in exchange for access to markets, or by leveraging the power of consumers who may, for instance, direct their purchases to firms that have some visible certification of their ethical conduct (Fransen and Conzelmann, 2015). There is a growing literature on how states, especially in the Global South, may maximize their jurisdiction's share of the value added in global value chains, for instance by adjusting labour, training or financial policies (Alford and Phillips, 2018; Egan, 2017; Jurowetzki et al., 2018).

On the governmental side, globalization has similarly involved a shift of policy issues to institutional settings operating globally or across national borders, such as the World Trade Organization or the European Union, but also in a proliferation of more informal fluid policy networks, often involving both public and private actors (Curran and Eckhardt, 2018; Djelic and den Hond, 2014; Slaughter, 2005). Under the label of global public policy, a range of public policies executed at the global level - not merely various international levels - come to our attention. In this perspective, emphasis is not only on the role of international bureaucracies or on the organizations as executors of negotiated compromises between states but, instead, the policies are foregrounded. Thus, traditions in the study of international affairs broadly speaking, such as theories of international regimes (Krasner, 1982), are fused with traditions in the study of public policy (Stone and Moloney, 2019). This requires that we examine the contents and problem-solving capacities of individual policies and analyse the different stages of policy-making, as the formulation and adoption of policy must be followed up by studies on implementation. Policy processes are often disaggregated into stages managed by quite separate actors or institutions, in contrast to earlier periods where these were more typically contained within a single state (Abbott and Snidal, 2009; Porter and Ronit, 2015).

The interweaving of public and private elements in globalized policy networks has raised many debates about whether this empowers business and leads to policy and regulatory capture, or if instead it allows government to more effectively leverage its limited resources, by extending its power through private rules and actors (Carpenter and Moss, 2014; Dal Bó, 2006; Pagliari, 2012; Young, 2012). These are important issues dealt with in the general literature on public policy discussed above and also relevant to the present challenges of globalization. Key factors that are pertinent to this debate include the degree to which these arrangements enable appropriate accountability, transparency and participation, on both the supply side of regulation and the demand side (Mattli and Woods, 2009). A useful concept is the "regulatory pyramid" developed by Ayres and Braithwaite (1992), where more routine compliance can be achieved by voluntary self-regulation, with series of escalations up the pyramid towards governmental coercive penalties in those less common cases of serious non-compliance. The involvement of civil society actors in these arrangements can be important in countervailing the influence of business actors and enhancing transparency and participation (Ronit, 2007a, 2007b).

One issue with the global policy process is that business often enjoys more structural power at the national level than it does at the international level, while civil 
society organizations often enhance influence over certain international institutions. They can extend their reach into member states, where the activities of international organizations and treaty secretariats are limited by sovereignty norms. The UN, for example, is prohibited by its charter from intruding into the domestic politics of member states (Kellow, 2002; Levy and Egan, 1998). This can limit the effectiveness of global policies, because - unlike "high politics" (issues relating to state integrity) - they usually require implementation at the national level (Hoffmann, 1966), and the greater power of business there can contribute to the phenomenon of the "vertical disintegration of policy" (Underdal, 1980).

Another of the many issues dealt with in global public policy is whether public policies can be developed fast enough to keep pace with developments in the market, as globalization poses significant problems for regulation (Reinicke, 1998). This can be seen as related to social acceleration, and the fluidity discussed above. Underlying this perspective is often the basic assumption that the economy and business as the principal drivers of the globalization of markets are important in the shaping of global policies. In this context, business may take multiple roles in the production of both public goods that are helpful in global governance, and in the creation of global bads that are detrimental to problem-solving (Kaul et al., 1999). Today, various sectors of business are, for instance, involved in tax evasion and it is a global challenge in public policy, but also damaging to reputation in certain areas of business, such as the financial industries (Eccleston and Elbra, 2018; Seabrooke and Wigan, 2017).

As the interactions between and governance of business and public policy have globalized, a vast and rich literature in the field of international political economy has provided relevant insights. This includes the building of the interests of business, or capital, into the growing density of transnational laws and other rules (Cutler and Dietz, 2017), a process that Gill (1998) labelled "the new constitutionalism" (Gill and Cutler, 2014). Particular attention has been devoted to the role of the International Monetary Fund and the World Bank in promoting business-friendly policies in the Global South. It also includes extensive exploration of the propensity of different domestic industry sectors or social classes to support or oppose the liberalization of global trade and investment, linking this, for instance, to the effects of relative scarcities of factors of production (Lake, 2009). This literature has extensively analysed the impact of globalization on the relative power of states and business interests, for instance highlighting the risks of a "race to the bottom" as competing jurisdictions weaken regulations to attract globally mobile businesses (Mosley and Uno, 2007). In this way, studies on domestic and global policies are combined. Vogel (1997) has shown, however, that business operating in multiple jurisdictions can drive a "race to the top" by seeking to export standards that it has already met, knowing that this will bring advantage over competitors which cannot yet meet these standards.

As business interests from the Global South have become stronger and more globally active, a growing international political economy literature has analysed their distinctive interactions with public policy. For instance Pepinsky (2013) has highlighted the ways in which local bankers in the Global South have an interest in opening their national borders to financial flows, but in restricting foreign ownership 
of local banks, thereby giving them a unique and powerful exclusive access to cheap funding for their national market. Samford (2015) explores the way that in response to consumer safety standards in export markets, the Mexican government worked creatively with multiple local stakeholders in the artisanal ceramic industry to rework regulation and production processes to remove toxic lead oxide. The interactions of local states and business interests with the types of governance associated with global value chains and private certifications have also received increasingly detailed analysis (Alford and Phillips, 2018), going beyond earlier tendencies to underestimate the independent power business in the Global South, or to focus on older forms of corporatism with centralized relationships between business and government elites and major problem-solving capacities hosted by associations in these countries (Doner and Schneider, 2000). Inspired by these new insights we need much more research into the significance of the growth of influential business interests from the Global South.

The field of international political economy has also generated a large literature on the role of US hegemony in the organization of the post-World War II liberal economic order. Hegemony involves unrivalled state power that nevertheless needs to use a mix of consent and coercion to organize a global order, fuelled and financed by the centralization of economic innovation in the territory of the hegemonic state (Wallerstein, 1983). As discussed further below, the current troubles of this US-led global order, the rise of nationalism, and the growing economic and political power of China and Chinese firms, evident for instance in the Belt and Road Initiative, raise many new and unanswered questions about what these geopolitical changes mean for the theory and practice of business and public policy globally (Flint and Zhu, 2019).

\section{BUSINESS AND PUBLIC POLICY: LOOKING TOWARDS THE FUTURE}

What lessons can we draw from the past decades of experience with business and public policy research and practice? We may identify continuities and trends that we can be confident will extend into the future, and that should be monitored and analysed to refine our understanding of this unfolding evolution. We may also identify uncertainties and gaps in our knowledge that urgently call for more research. In this concluding section, we look at both in turn.

The story of these past decades is one of the relationship between business and public policy shifting from interactions within national territorial borders to more globalized forms of organization in business-government relations. A pertinent question, however, is whether these interactions have become more decentralized or centralized in these processes of multi-level policy-making. In many policy fields, the formulation and implementation is not autonomously accomplished at national levels and then aggregated at the global level. Increasingly, we have seen that global bodies in the business community and intergovernmental organizations adopt approaches and regulations that set conditions for public policy at domestic levels. However, 
this development should not be seen as deterministic. In the case of COVID-19, for instance, many policies pertaining to business are adopted at domestic levels and are not aggregated at global levels, and globalization of policy-making faces a number of important limitations.

Second, a related problem is the future roles of market and state in influencing public policy. Recent decades have brought very mixed experiences. The collapse of the Soviet empire seemed to discredit the role of state-led economies, and in many sectors of the economy, for instance the financial industries and telecommunications, the answer was in many countries sought in deregulation. Also the development of New Public Management thinking put more emphasis on market rather than state, thereby changing the general conditions of business and public policy and the situation in specific sectors of business. However, we have also other trends. The state-led economy of China has been very successful and has developed new approaches that challenge the strong role of markets and attribute a much stronger role to governments. It also seems that the call for climate change will involve business to a very high degree but in a process that is highly encouraged and assisted by governments and intergovernmental organizations, defining new policies for business.

Third, the actors and stages involved in public policy have moved out and beyond the state, activating business and civil society in new ways. Indeed, there are claims that business needs a stronger social license to operate, and this is not provided by government alone. These new forms of organization often involve complex mixes of public, private and civil society actors and governance mechanisms. For instance, the governance effect of a private scheme, such as certification in the agri-food industry, may draw upon the technical and authoritative capacities of a private certification body, where the ethical concerns of consumers, the reputational effects of criticisms from civil society organizations, the food safety concerns of large food retailers, and the implicit threat of governmental intervention if food problems emerge, are factors of great importance (Nestle, 2013). However, civil society has difficulties in mobilizing a collective voice in many markets. A different future scenario is therefore that strong corporations manage to capture public policy without involving civil society.

We may also identify daunting future policy challenges that call for us to expand our imagination and research efforts in even more far-reaching ways. Three such interrelated challenges are especially important: the environment, disruptive technologies, and the global order.

The environment poses a multifaceted challenge for business and public policy. For instance, climate policy, a new and emerging policy field, is in many ways also a hybrid that combines different policies and concerns, and it is clearly a policy field that divides business (Pinkse and Kolk, 2009). Business is part of the problem, for instance when it lobbies against environmental regulations, and part of the solution, as with the development of cleaner technologies. These hybrids will be challenging to both individual industries and business in general because they fuse different types of public policy and adaptation to changing agendas is required. Therefore, we need to get a better empirical and theoretical grasp of these hybrids. Many insights can be won when we focus on the combination of policy fields, such as competition and 
consumer policy or trade and environment policy where crucial business interests are at stake.

Disruptive technologies such as artificial intelligence, social media, genetic engineering, video streaming, ride sharing, or 3D printing, offer exciting new benefits, but also destabilizing risks for the jobs, firms, and public policies that they challenge. Often the firms that create these technologies do not align with or participate in conventional industry boundaries and the governance institutions associated with them. Where platforms are involved, their network effects can contribute to market dominance, as with Google Search, and architectures and complexity of the technology can obscure their operations and weaken their accountabilities (Srnicek, 2017; Zuboff, 2019). Governmental actors face difficult trade-offs in their efforts to both enhance the growth of these new technologies, and to regulate their risks and destructive effects. In general, the literature calls for more widespread and diverse bottom-up participation in the early design stages of these technologies, but far more research is needed into the business and public policy challenges that these technologies pose (Christensen at al., 2018; OECD, 2018; World Economic Forum, 2017).

As noted above, the US-led global order that has been dominant since World War II is being challenged by the backlashes against globalization and democracy. Over these decades the institutions and activities associated with business and public policy have often been taken for granted, without fully considering their dependence on this global order. The problems of the global order are multidimensional, including its failures to address wealth inequalities, its underinvestment in public infrastructures, dishearteningly evident in the failures of global public health infrastructures in the COVID-19 pandemic, the fracturing of the domestic and global political alliances that stabilized it, and challenges to trust in science and professional expertise, and the depoliticization of public policy problems that this trust enabled, often a key enabling feature of governance arrangements associated with business and public policy. The stability of the global order had also relied upon the heavy concentration of industry and business power in the Global North, facilitating coordination of governance in institutions such as the G7. There are a multitude of business and politics research questions that the troubles of the global liberal order provoke. For instance, how do our theories need to change to recognize variation in local conditions in settings beyond those in the Global North in which they were developed? What new domestic alliances will business forge in response to popular resistance to the perceived negative consequences of their role in the global order, such as environmental harms, health pandemics, or social precarity? Are institutions crucial to business, such as the World Trade Organization, politically sustainable with the stresses in the global order?

While uncertainties about the future of business and public policy proliferate, we know that this relationship and the work of those who study it will likely become even more crucial, as we seek solutions to increasingly challenging problems amid growing complexity and the ongoing destabilization of existing institutional arrangements. As this work continues to advance, it will build on the decades of insights that have illuminated the central role played by business in national and global public pol- 
icies, refining those insights and providing new answers in response to the challenges that this evolving history is generating.

\section{REFERENCES}

Abbott, Kenneth W. and Duncan Snidal. 2009. "The Governance Triangle: Regulatory Standards Institutions and the Shadow of the State." In The Politics of Global Regulation, ed. Walter Mattli and Ngaire Woods. Princeton, NJ: Princeton University Press, 44-88.

Alford, Matthew and Nicola Phillips. 2018. "The political economy of state governance in global production networks: Change, crisis and contestation in the South African fruit sector." Review of International Political Economy 25(1): 98-121.

Atkinson, Michael M. and William D. Coleman. 1992. "Policy Networks, Policy Communities and the Problems of Governance." Governance 5(2): 154-180.

Ayres, Ian and John Braithwaite. 1992. Responsive Regulation: Transcending the Deregulation Debate. New York: Oxford University Press.

Bachrach, P. and M. Baratz. 1963. "Decisions and Nondecisions: An Analytical Framework." American Political Science Review 57: 641-651.

Baker, Andrew. 1999. 'Nebuleuse and the 'internationalization of the state' in the UK? The case of HM Treasury and the Bank of England." Review of International Political Economy 6(1): 79-100.

Baldwin, R., M. Cave and M. Lodge. 2012. Understanding Regulation: Theory, Strategy, and Practice. Oxford: Oxford University Press.

Barrow, Clyde W. 2002. "The Miliband-Poulantzas debate: An intellectual history." In Paradigm Lost: State Theory Reconsidered, ed. Stanley Aronowitz and Peter Bratsis. Minneapolis, MN: University of Minnesota Press, 3-52.

Braithwaite, John and Peter Drahos. 2000. Global Business Regulation. Cambridge: Cambridge University Press.

Carpenter, Daniel P. and David A. Moss, eds. 2014. Preventing Regulatory Capture: Special Interest Influence and How to Limit It. New York: Cambridge University Press.

Carroll, A. B. 2008. "History of corporate social responsibility: Concepts and practices." In The Oxford Handbook of Corporate Social Responsibility, ed. A. Crane, D. Matten, A. McWilliams, J. Moon and D. S. Siegel. Oxford: Oxford University Press, 19-46.

Castells, Manuel. 2000. The Rise of the Network Society, 2nd edition. Oxford: Blackwell Publishers.

Christensen, Clayton M., Rory McDonald, Elizabeth J. Altman and Jonathan E. Palmer. 2018. "Disruptive innovation: An intellectual history and directions for future research." Journal of Management Studies 55(7): 1043-1078.

Crasnic, Loriana, Nikhil Kalyanpur and Abraham Newman. 2017. "Networked liabilities: Transnational authority in a world of transnational business." European Journal of International Relations 23(4): 906-929.

Curran, Louise and Jappe Eckhardt. 2018. "Influencing trade policy in a multi-level system: Understanding corporate political activity in the context of global value chains and regime complexity." Business and Politics 20(1): 132-164.

Cutler, A. Claire and Thomas Dietz. 2017. The Politics of Private Transnational Governance by Contract. London and New York: Routledge.

Dahl, R. A. 1973. Polyarchy: Participation and Opposition. New Haven, CT: Yale University Press.

Dal Bó, Ernesto. 2006. "Regulatory capture: A review." Oxford Review of Economic Policy 22(2): 203-225. 
De Búrca, Gráinne, Robert O. Keohane and Charles Sabel. 2014. "Global experimentalist governance." British Journal of Political Science 44(3): 477-486.

De Goede, Marieke. 2001. "Discourses of scientific finance and the failure of long-term capital management." New Political Economy 6(2): 149-170.

Djelic, Marie Laure and Frank den Hond. 2014. "Introduction: Multiplicity and plurality in the world of standards." Business and Politics 16(1): 67-77.

Doner, Richard F. and Ben Ross Schneider. 2000. "Business associations and economic development: Why some associations contribute more than others." Business and Politics 2(3): 261-288.

Eccleston, R. and A. Elbra, eds. 2018. Business, Civil Society and the 'New' Politics of Corporate Tax Justice: Paying a Fair Share? Cheltenham, UK and Northampton, MA, USA: Edward Elgar Publishing.

Egan, Patrick. 2017. Globalizing Innovation: State Institutions and Foreign Direct Investment in Emerging Economies. Cambridge, MA: MIT Press.

Ferguson, Niall. 2018. The Square and the Tower: Networks and Power, from the Freemasons to Facebook. New York: Penguin.

Fligstein, Neil. 2013. The Transformation of Corporate Control. Cambridge, MA: Harvard University Press.

Flint, Colin and Cuiping Zhu. 2019. "The geopolitics of connectivity, cooperation, and hegemonic competition: The Belt and Road initiative." Geoforum 99: 95-101.

Fransen, Luc and Thomas Conzelmann. 2015. "Fragmented or cohesive transnational private regulation of sustainability standards? A comparative study." Regulation \& Governance 9(3): 259-275.

Fuchs, Doris A. 2005. Understanding Business Power in Global Governance. Baden-Baden: Nomos.

Fuchs, Doris A. 2007. Business Power in Global Governance. Boulder, CO: Lynne Rienner.

Galbraith, John Kenneth. 1952. American Capitalism: The Concept of Countervailing Power. Boston: Houghton-Mifflin.

Gereffi, Gary. 2014. "Global value chains in a post-Washington Consensus world." Review of International Political Economy 21(1): 9-37.

Gill, Stephen. 1998. "New constitutionalism, democratisation and global political economy." Pacifica Review: Peace, Security \& Global Change 10(1): 23-38.

Gill, Stephen and A. Claire Cutler, eds. 2014. New Constitutionalism and World Order. New York: Cambridge University Press.

Greif, Avner. 2005. "Commitment, coercion, and markets: The nature and dynamics of institutions supporting exchange." In Handbook of New Institutional Economics, ed. C. Ménard and M. M. Shirley. Berlin: Springer, 727-786.

Grote, Jürgen, Achim Lang and Volker Schneider, eds. 2008. Organized Business Interests in Changing Environments: The Complexity of Adaptation. Basingstoke: Palgrave Macmillan.

Grote, Jürgen R. and Philippe C. Schmitter. 1999. "The renaissance of national corporatism: Unintended side-effect of European Economic and Monetary Union or calculated response to the absence of European social policy?" Transfer: European Review of Labour and Research 5(1-2): 34-63.

Gunningham, Neil, Martin Phillipson and Peter Grabosky. 1999. "Harnessing third parties as surrogate regulators: Achieving environmental outcomes by alternative means." Business Strategy and the Environment 8(4): 211-224.

Hall, Peter A. and David W. Soskice, eds. 2001. Varieties of Capitalism: The Institutional Foundations of Comparative Advantage. New York: Oxford University Press.

Havinga, Tetty. 2015. "Conceptualizing regulatory arrangements: Complex networks and regulatory roles." In The Changing Landscape of Food Governance: Public and Private Encounters, ed. T. Havinga, F. van Waarden and D. Casey. Cheltenham, UK and Northampton, MA, USA: Edward Elgar Publishing, 19-36. 
Hoffmann, S. 1966. "Obstinate or obsolete? The fate of the nation-state and the case of Western Europe.” Daedalus 95(3): 862-915.

Hollingsworth, J. Rogers and Robert Boyer. 1997a. "Coordination of economic actors and social systems of production." In Contemporary Capitalism: The Embeddedness of Institutions, ed. J. Rogers Hollingsworth and Robert Boyer. Cambridge: Cambridge University Press, 1-47.

Hollingsworth, J. Rogers and Robert Boyer, eds. 1997b. Contemporary Capitalism: The Embeddedness of Institutions. Cambridge: Cambridge University Press.

Jurowetzki, Roman, Rasmus Lema and Bengt-Åke Lundvall. 2018. "Combining innovation systems and global value chains for development: Towards a research agenda." The European Journal of Development Research 30(3): 364-388.

Kaul, Inge, Isabelle Grunberg and Marc A. Stern, eds. 1999. Global Public Goods: International Cooperation in the 21st Century. Oxford: Oxford University Press.

Kellow, Aynsley. 2002. "Comparing business and public interest associability at the international level." International Political Science Review 23(2): 175-186.

Krasner, Stephen D., ed. 1982. International Regimes. Ithaca, NY: Cornell University Press.

Lake, David A. 2009. "Open economy politics: A critical review." The Review of International Organizations 4(3): 219-244.

Lehmbruch, G. 1984. "Concertation and the structure of corporatist networks." In Order and Conflict in Contemporary Capitalism, ed. J. H. Goldthorpe. Oxford: Clarendon Press, 60-80.

Levy, D. L. and D. Egan. 1998. "Capital contests: National and transnational channels of corporate influence on the climate change negotiations." Politics \& Society 26(3): 337-361.

Lindblom, C. E. 1983. Politics and Markets: The World's Political-Economic Systems. New York: Basic Books.

Lowi, T. J. 1964. "American business, public policy, case-studies, and political theory." World Politics 16(4): 677-715.

Lowi, T. J. 2001. "Our millennium: Political science confronts the global corporate economy." International Political Science Review 22(2): 131-150.

MacKenzie, Donald. 2008. An Engine, Not a Camera: How Financial Models Shape Markets. Cambridge, MA: MIT Press.

Manow, Philip and Bernhard Ebbinghaus, eds. 2006. Comparing Welfare Capitalism: Social Policy and Political Economy in Europe, Japan and the USA. London: Routledge.

Mattli, Walter and Ngaire Woods, eds. 2009. The Politics of Global Regulation. Princeton, NJ: Princeton University Press.

Mosley, Layna and Saika Uno. 2007. "Racing to the bottom or climbing to the top? Economic globalization and collective labor rights." Comparative Political Studies 40(8): 923-948.

Muzaka, Valbona. 2009. "Shaping global rules: Proprietary pharmaceutical companies as global political actors." New Political Economy 14(2): 289-301.

Nestle, Marion. 2013. Food Politics: How the Food Industry Influences Nutrition and Health. Berkeley: University of California Press.

Nölke, Andreas and Christian May. 2018. "The delusion of the global corporation: Introduction to the Handbook." In Handbook of the International Political Economy of the Corporation, ed. Andreas Nölke and Christian May. Cheltenham, UK and Northampton, MA, USA: Edward Elgar Publishing, 1-25.

OECD. 2018. Adapting to Technological and Societal Disruption. Paris: Organisation for Economic Co-operation and Development.

Offe, C. and H. Wiesenthal. 1980. "Two logics of collective action: Theoretical notes on social class and organizational form." Political Power and Social Theory 1(1): 67-115.

Olson, Mancur. 1965. The Logic of Collective Action: Public Goods and the Theory of Groups. Cambridge, MA: Harvard University Press. 
Overdevest, Christine and Jonathan Zeitlin. 2018. "Experimentalism in transnational forest governance: Implementing European Union Forest Law Enforcement, Governance and Trade (FLEGT) voluntary partnership agreements in Indonesia and Ghana: Transnational forest governance." Regulation \& Governance 12(1): 64-87.

Pagliari, Stefano, ed. 2012. The Making of Good Financial Regulation: Towards a Policy Response to Regulatory Capture. London: International Centre for Financial Regulation.

Pepinsky, Thomas B. 2013. "The domestic politics of financial internationalization in the developing world." Review of International Political Economy 20(4): 848-880.

Pierson, Paul. 1993. "When effect becomes cause: Policy feedback and political change." World Politics 45: 595-628.

Pierson, Paul. 2006. "Public policies as institutions." In Rethinking Political Institutions: The Art of the State, ed. I. Shapiro, S. Skowronek and D. Galvin. New York: New York University Press, 114-131.

Pinkse, J. and A. Kolk. 2009. International Business and Global Climate Change. London: Routledge.

Piore, Michael J. and Charles F. Sabel. 2000. The Second Industrial Divide: Possibilities for Prosperity. New York: Basic Books.

Ponte, Stefano and Timothy Sturgeon. 2014. "Explaining governance in global value chains: A modular theory-building effort." Review of International Political Economy 21(1): 195-223.

Porter, Tony. 1999. "Hegemony and the private governance of international industries." In Private Authority in International Affairs, ed. A. C. Cutler, V. Haufler and T. Porter. Albany: SUNY Press, 257-282.

Porter, Tony and Karsten Ronit. 2015. "Implementation in international business self-regulation: The importance of sequences and their linkages." Journal of Law and Society 42(3): 413-433.

Reinicke, Wolfgang H. 1998. Global Public Policy: Governing without Government. Washington, DC: Brookings Institution.

Ronit, Karsten. 2007a. "Introduction: Global public policy - the new policy arrangements of business and countervailing groups." In Global Public Policy: Business and the Countervailing Powers of Civil Society, ed. Karsten Ronit. London: Routledge, 1-42.

Ronit, Karsten, ed. 2007b. Global Public Policy: Business and the Countervailing Powers of Civil Society. London: Routledge.

Ronit, Karsten. 2018. Global Business Associations. London: Routledge.

Rosa, Hartmut. 2015. Social Acceleration: A New Theory of Modernity. New York: Columbia University Press.

Ruggie, John Gerard. 2014. Just Business: Multinational Corporations and Human Rights. New York: W. W. Norton.

Ruggie, John Gerard. 2018. "Multinationals as global institution: Power, authority and relative autonomy." Regulation \& Governance 12(3): 317-333.

Salisbury, Robert H. 1984. "Interest representation: The dominance of institutions." American Political Science Review 78(1): 64-76.

Samford, Steven. 2015. "Innovation and public space: The developmental possibilities of regulation in the global south." Regulation \& Governance 9(3): 294-308.

Schattschneider, E. E. 1975. The Semisovereign People: A Realist's View of Democracy in America, 2nd edition. Hinsdale, IL: The Dryden Press.

Schmitter, P. C. 1974. "Still the century of corporatism?" The Review of Politics 36(1): 85-131.

Schmitter, P. C. and W. Streeck. 1999. The Organization of Business Interests: Studying the Associative Action of Business in Advanced Industrial Societies. MPIfG discussion paper 99/1. Cologne: Max Planck Institute. 
Seabrooke, Leonard and Duncan Wigan. 2017. "The governance of global wealth chains." Review of International Political Economy 24(1): 1-29.

Slaughter, Anne-Marie. 2005. A New World Order. Princeton, NJ: Princeton University Press.

Slaughter, Anne-Marie. 2017. The Chessboard and the Web: Strategies of Connection in a Networked World. New Haven, CT: Yale University Press.

Soederberg, Susanne, Georg Menz and Philip G. Cerny. 2005. Internalizing Globalization: The Rise of Neoliberalism and the Decline of National Varieties of Capitalism. Basingstoke: Palgrave Macmillan.

Srnicek, Nick. 2017. Platform Capitalism. Cambridge: Polity Press.

Stone, Diane and Kim Moloney, eds. 2019. The Oxford Handbook of Global Policy and Transnational Administration. Oxford: Oxford University Press.

Streeck, Wolfgang and Philippe C. Schmitter. 1985. "Community, market, state-and associations? The prospective contribution of interest governance to social order." European Sociological Review 1(2): 119-138.

Traxler, Franz and Philippe C. Schmitter. 1995. "The emerging Euro-polity and organized interests.” European Journal of International Relations 1(2): 191-218.

Truman, D. B. 1971. The Governmental Process. New York: Alfred A. Knopf.

Tsingou, Eleni. 2014. "Power elites and club-model governance in global finance." International Political Sociology 8(3): 340-342.

Underdal, A. 1980. The Politics of International Fisheries Management: The Case of the North-East Atlantic. New York: Columbia University Press.

Vogel, David. 1989. Fluctuating Fortunes: The Political Power of Business in America. New York: Basic Books.

Vogel, David. 1997. "Trading up and governing across: Transnational governance and environmental protection." Journal of European Public Policy 4(4): 556-571.

Vogel, David. 2007. The Market for Virtue: The Potential and Limits of Corporate Social Responsibility. Washington, DC: Brookings Institution.

Wallerstein, I. 1983. "The three instances of hegemony in the history of the capitalist world-economy." International Journal of Comparative Sociology 24(1-2): 100-108.

Watson, Daniel. 2019. "Fordism: A review essay." Labor History 60(2): 144-159.

Whitley, Richard. 2007. Business Systems and Organizational Capabilities: The Institutional Structuring of Competitive Competences. New York: Oxford University Press.

World Economic Forum. 2017. Agile Governance: Reimagining Policy-Making in the Fourth Industrial Revolution. White paper. http://www3.weforum.org/docs/WEF_Agile _Governance_Reimagining_Policy-making_4IR_report.pdf.

Yandle, B. 1983. "Bootleggers and Baptists: The education of a regulatory economist." Regulation 7: 12-16.

Yandle, B. and S. Buck. 2002. "Bootleggers, Baptists, and the global warming battle." Harvard Environmental Law Review 26: 177-229.

Young, Kevin L. 2012. "Transnational regulatory capture? An empirical examination of the transnational lobbying of the Basel Committee on Banking Supervision." Review of International Political Economy 19(4): 663-688.

Zeitlin, Jonathan, ed. 2015. Extending Experimentalist Governance? The European Union and Transnational Regulation. Oxford: Oxford University Press.

Zuboff, Shoshana. 2019. The Age of Surveillance Capitalism: The Fight for a Human Future at the New Frontier of Power. New York: Public Affairs. 